\title{
Social Isolation, Loneliness and Return Migration: Evidence from Older Irish Adults
}

\section{Alan Barrett \& Irene Mosca}

To cite this article: Alan Barrett \& Irene Mosca (2013) Social Isolation, Loneliness and Return Migration: Evidence from Older Irish Adults, Journal of Ethnic and Migration Studies, 39:10, 1659-1677, DOI: 10.1080/1369183X.2013.833694

To link to this article: https://doi.org/10.1080/1369183X.2013.833694

册Published online: 13 Sep 2013.

Submit your article to this journal $ऍ$

Џlll Article views: 638

Citing articles: 15 View citing articles $\square$ 


\title{
Social Isolation, Loneliness and Return Migration: Evidence from Older Irish Adults
}

\author{
Alan Barrett and Irene Mosca
}

Across the subjects of economics, sociology and demography, much has been written about the difficulties faced by immigrants. However, much less attention has been paid to the difficulties which return migrants face when they come back to live in their countries of birth. A number of studies suggest that return migrants can experience significant re-adjustment challenges. In this paper, we add to this strand of research by examining the extent to which a group of returned migrants experience higher degrees of social isolation and loneliness compared to compatriots who never lived outside their country of birth. The data used are from the first wave of the Irish Longitudinal Study on Ageing (TILDA). Our results suggest that social isolation is a significant feature of the lives of return migrants and that the degree of social isolation is typically stronger for people who spent longer away and who have returned more recently.

Keywords: Return Migrants; Older Adults; Ireland; Social Participation; Loneliness

\section{Introduction}

From several disciplinary perspectives, much has been written about the difficulties faced by immigrants in adjusting to life in their destinations. These difficulties range from the more modest forms, such as homesickness, to extreme forms such as discrimination and violent hostility. Between these extremes, immigrants have been shown to experience difficulties in accessing employment, social support and housing.

While the situation of immigrants has been extensively studied, much less attention has been paid to the difficulties which return migrants face when they come back to live in their countries of birth. This relative lack of research may be based on a view that once immigrants have returned to their home country, they

\footnotetext{
Alan Barrett and Irene Mosca are respectively Research Professor of Economics and Research Fellow in Economics within The Irish Longitudinal Study on Ageing (TILDA) at Trinity College Dublin. Correspondence to: Prof. A. Barrett/Dr I. Mosca, TILDA, Lincoln Gate, Trinity College Dublin, Dublin 2, Republic of Ireland. E-mails: barretal@tcd.ie; moscai@tcd.ie
} 
blend back in and are then essentially no different to other natives in that country of origin. However, a number of studies which we describe below suggest that return migrants can experience significant re-adjustment challenges.

In this paper, we contribute to this literature by examining returned migrants' experiences, to determine whether they suffered from higher degrees of social isolation and loneliness compared to compatriots who never lived outside their country of birth. Given Ireland's long history of migration (and return migration), the large and nationally representative sample of older Irish adults from the first wave of the Irish Longitudinal Study on Ageing (TILDA) provides a uniquely valuable resource upon which to base research on the experiences of returned migrants.

Our research question is current and important for a variety of reasons. International migration has increased significantly in the last decade in Europe. According to estimates on international migration from Eurostat, 2.3 million people left their country of origin in 2008 alone. Although it is difficult to predict how many migrants will return home, previous studies have estimated return migration rates in Europe in the range of 70 to 85 per cent (Böhning 1987; Glytsos 1988). For countries or regions which will face significant populations of (older) returned migrants, a high prevalence of social isolation will have implications for the use and delivery of social services.

At an individual level, the implications are clearly more immediate. The absence of loneliness and social isolation is seen as an important factor for a good quality of life (Sinclair et al. 1990). A number of international studies have also shown a strong positive association between social engagement and physical, cognitive and mental health outcomes, especially for older people (Conroy et al. 2010; Glass et al. 2006; Rodriguez et al. 2011; Seeman et al. 2010; Sirven and Debrand 2008). Similarly, loneliness has been shown to predict a wide variety of mental and physical health outcomes, such as depression, nursing-home admission, and mortality (Conroy et al. 2010; Grenade and Boldy 2008; Hawkley et al. 2010; O'Luanaigh and Lawlor 2008).

The remainder of the paper is structured as follows. We first review the literature on the re-adjustment experiences of return migrants and investigate historical Irish migration. We then describe the data used in the empirical analysis, illustrate the methodology employed in our paper and present both descriptive statistics and the results from the econometric analysis. Finally, we provide some conclusions.

\section{The Re-Adjustment Experiences of Return Migrants: Evidence from Previous Studies}

Many empirical studies, almost all qualitative in nature, have highlighted the sense of disappointment and isolation, and the feelings of alienation and not-belonging experienced by migrants on their return to the home country (Christou 2006; Constable 1999; Long and Oxfeld 2004). Cerase (1967, 1970, 1974) investigated the re-adjustment experiences of Italian migrants from the US in the 1960s and 1970s. He found that the longer the time spent away, the more difficult the reintegration in Italy, with those who spent less than ten years in the US facing the fewest difficulties. In 
her study on second-generation Greek-American returning migrants, Christou found that return migrants 'were disappointed in finding that Greece, Greeks and Greek ways of life were not as "pure" as they had imagined' and 'were dissatisfied with their material circumstances and prospects following "return” migration' (2006: 832).

In the Irish context, four studies are of particular interest: Gmelch $(1986,1987)$, McGrath (1991), Ní Laoire (2007, 2008) and Ryan (2008). In 1977-8, Gmelch (1986, 1987) and his collaborators interviewed 606 Irish migrants who had lived abroad for at least two years and then returned to Ireland and settled down in small communities in the west of the country. Fifty-one per cent of return migrants stated that they were not satisfied with their lives in Ireland during their first year back. This compared to 21 per cent for those who had been back for two or more years and 17 per cent for those who had been back for more than five years. Return migrants also felt that their interests were different from those of the local people and encountered problems in re-establishing relationships with friends and relatives at the pre-migration level of intimacy. The difficulties encountered in re-establishing relationships increased with the time spent abroad. Eighty five per cent of respondents stated that they felt different from stayers.

McGrath (1991) investigated the experiences of 142 migrants who returned to Achill Island in the West of Ireland. The main reason for return was the desire to be close to family and friends or to care for (older) relatives. McGrath (1991) found that the returned migrants remained a separate and distinct community. Most returners faced a range of re-adjustment problems, including the lack of employment opportunities and the inefficiency and slow pace of island life. Sixty per cent of the return migrants interviewed did not belong to a club, compared to 27.3 per cent of stayers. Stayers also tended to belong to or organise several clubs, compared to only one or two for return migrants. Return migrants were also twice as likely as stayers to have return migrants as their closest friends. More than a quarter of returnees 'definitely intended to reemigrate' (McGrath 1991: 63).

Ní Laoire $(2007,2008)$ collected 33 life narratives of migrants who left Ireland between the late 1970s and the early 1990s, and returned home in the mid-1990s and early 2000s. She concluded that "narratives of "not quite belonging" recur[red] among return migrants' (2008: 40).

Ryan (2008) interviewed 25 Irish nurses who migrated to Britain in the 1940s to 1960s and were retired and still living in Britain when interviewed. She concluded that many of the women felt disconnected from the culture, lifestyle and values of twenty-first-century Irish society. Two of them had previously moved back to Ireland but 'in both cases these women found it impossible to settle back into Irish society and decided to re-migrate' (2008: 132).

\section{Historical Overview of Irish Migration}

The topic of migration has been of enormous importance for Ireland since the early part of the last century. For much of the twentieth century, emigration from Ireland 
Table 1. Net migration flows and rates in Ireland, 1926-91 (annual averages)

\begin{tabular}{|c|c|c|c|c|}
\hline \multirow{2}{*}{$\begin{array}{l}\text { Intercensal } \\
\text { period }\end{array}$} & \multicolumn{3}{|c|}{ Net migration } & \multirow{2}{*}{$\begin{array}{l}\text { Net migration rate over } 1,000 \text { average } \\
\text { population }\end{array}$} \\
\hline & Males & Females & Total & \\
\hline $1926-36$ & $-7,255$ & $-9,420$ & $-16,675$ & -5.6 \\
\hline $1936-46$ & $-11,258$ & $-7,453$ & $-18,711$ & -6.3 \\
\hline $1946-51$ & $-10,309$ & $-14,075$ & $-24,384$ & -8.2 \\
\hline $1951-61$ & $-21,786$ & $-19,091$ & $-40,877$ & -14.1 \\
\hline $1961-71$ & $-6,236$ & $-7,215$ & $-13,451$ & -4.6 \\
\hline $1971-81$ & $+5,806$ & $+4,583$ & $+10,389$ & +3.2 \\
\hline 1981-91 & $-8,283$ & $-6,094$ & $-14,377$ & -5.9 \\
\hline
\end{tabular}

Source: 1926-86 taken from NESC (1991); 1986-91 from Sexton (1996).

was high and population decline continued until 1961. Even in the 1960s, when the population grew, emigration continued. The 1970s saw unprecedented inflows; however, net outflows resumed in the 1980s, thereby leaving emigration as a defining feature of Ireland's demographic and economic experience.

Table 1 shows net migration flows and rates in Ireland in the period which is of the most interest for our research (i.e. up to the early 1990s). We can see that, on an annual basis, net outward migration averaged 1.41 per cent of the population in the 1950 s and 0.46 per cent in the 1960s. These outflows were counterbalanced by net inflows in the 1970s of 0.32 per cent. However, net outward migration averaged 0.59 per cent of the population in the 1980s.

With regard to the destinations of Ireland's emigrants, a major shift occurred at the beginning of the 1930s. Between 1880 and 1921, 87 per cent of emigrants went to the United States and only 10 per cent went to Britain. However, it is estimated that, by the late 1940s, over 80 per cent of the outflow went to Britain and this continued in the 1970s (Barrett 2005). The outflow was concentrated in the 15-24 age category and so emigration was a young, and mostly single person's pursuit (Leavey et al. 2004).

The literature on the Irish experience in Britain has revealed that most individuals migrated for economic reasons, although this generally co-existed with a 'push' factor of desire to escape or change (Gmelch 1986, 1987; Leavey et al. 2004; Ryan 2008).

\section{Data}

Data from the first wave (2009/2011) of The Irish Longitudinal Study on Ageing (TILDA) are used in the analysis below. This is a large and nationally representative study of people aged 50 and over (and their spouses or partners of any age) resident in Ireland. TILDA collects detailed information on all aspects of the respondents' lives, including the economic dimension, health aspects and the social domain. Full details of the sampling procedure and methodology of TILDA can be found in Kenny et al. (2010) and Savva (2011).

TILDA also collects information on previous migration experiences. Individuals are asked if they have ever lived outside Ireland for at least six months. If they answer 
'Yes', individuals are coded as 'return migrants'; if they answer 'No', they are coded as 'stayers'.

Information on the total number of years spent abroad and age at first migration is also collected. Using the information on the total number of years spent abroad, we divide return migrants into two categories-short-term and long-term return migrants. We investigated different cut-off points to distinguish between them. In our preferred specification, short-term migrants are classified as those who lived abroad for one to nine years and long-term migrants as those who lived in another country for 10 years or more. However, if a lower cut-off point was to be chosen (e.g. five years), the results of our models would not change significantly. Using information on current age, age at migration and number of years spent abroad, we are also able to distinguish between those who returned to Ireland in the last decade (recent returners) and those who returned at an earlier stage (earlier returners). ${ }^{1}$

In the TILDA sample, 24 per cent of men and 21 per cent of women have lived abroad for at least six months; 46 per cent of the male return migrants and 43 per cent of female return migrants have lived abroad for at least 10 years; and 67 per cent of men and 74 per cent of women left Ireland for the first time when aged 16-24.

\section{Methodology}

\section{Outcome Variables and Model Specification}

There are different ways to describe older adults' engagement (or lack of) in social activities, the type and number of social connections they have and their loneliness. Although social isolation and loneliness are sometimes referred to as similar/identical concepts, they are separate ones and do not necessarily co-occur. Social isolation is an objective measure and refers to the absence of relationships/minimal contact with other people. Loneliness is a subjective measure and refers to the feeling of missing intimate relationships, a specific desired companion or a wider network (Wenger et al. 1996).

We employ three different models in our paper. In Model 1, we measure social connectedness using an adapted version of the Berkman-Syme Social Network Index (Berkman and Syme 1979). This index includes four components: 1) marital status: a dummy variable equal to one if the individual is married or cohabiting-zero otherwise; 2) presence of close children, relatives or friends: a dummy variable equal to one if the individual has at least two children, other relatives or friends she feels close to-zero otherwise; 3) membership of church groups: a dummy variable equal to one if the individual attends religious services at least once per month-zero otherwise; and 4) membership of community organisations: a dummy variable equal to one if the individual participates in any groups such as a sports or social group or club, a church-connected group, a voluntary association, a self-help or charitable body or other community group or a day-care centre-zero otherwise. Each connection type is scored either zero or one and the four scores are summed to create four levels (0-4) of social connection or engagement: very isolated (0-1), moderately isolated (2), moderately integrated (3) and very integrated (4). We employ 
a standard probit model in which the outcome variable is equal to one if the individual is moderately or very isolated according to the Berkman-Syme Social Network Index and zero if s/he is moderately or very integrated (Model 1).

We then turn to Model 2, in which we investigate close ties in more detail. We employ an Ordinary Least Squares (OLS) model in which the dependent variable is the sum of close friends, children or other relatives.

We finally investigate Model 3, which focuses on loneliness. In TILDA, loneliness is measured using a modified version of the University of California Los Angeles (UCLA) Loneliness Scale (Russell 1996). Four negatively worded and one positively worded questions are used: How often do you feel a lack of companionship? How often do you feel left out? How often do you feel isolated from others? How often do you feel lonely? How often do you feel in tune with the people around you? The frequency of the outcome variable is assessed as: 'Hardly ever or never'; 'Some of the time'; or 'Often'. The responses to the five questions are summed and the final score can range from zero (not lonely) to 10 (extremely lonely). We employ a two-limit tobit model, where the two 'limits' are the lowest (zero) and highest (10) possible scores.

\section{Explanatory Variables}

Focusing first on the variables which are of the most interest for us, we control for return migration, distinguishing between short-term and long-term migration and for number of years since return. We include three migration dummy variables in the model, with an omitted/reference category of stayers: i) a dummy variable equal to one if the individual is a short-term migrant (one to nine years spent abroad) - zero otherwise; ii) a dummy variable equal to one if the individual is a long-term recent returner (10 or more years spent in another country and returned to Ireland in the last decade)—zero otherwise; iii) a dummy variable equal to one if the individual is a long-term earlier returner (10 or more years spent in another country and returned to Ireland at least 11 years prior to the interview) - zero otherwise. ${ }^{2}$

We then control for a number of 'standard' socio-economic characteristics that are associated with the outcome variables, including:

- age;

- educational attainment: highest qualification attained, in three categories: primary or none, secondary, and third or higher;

- current self-reported labour market status, in five categories: employed, retired, permanently sick or disabled, unemployed, and other;

- current area of residence, in three categories: Dublin, town/city other than Dublin, rural area;

- current self-reported health: a dummy variable for whether the respondent selfrates her current health as fair or poor;

- number of living children and siblings;

- a dummy variable for whether or not the mother (father) is alive; 
- socio-economic status in childhood: a dummy variable for whether or not the respondent was living in a rural area at age 14 and for whether or not the respondent grew up in a poor family; and

- health in childhood: a dummy variable for whether or the respondent self-rates his/her health in childhood (from birth to age 14) as poor.

In Models 2 and 3 we also control for whether the respondent is married or cohabiting. The same does not apply to Model 1, given that being married or cohabiting is one of the four components of the Berkman-Syme Social Network Index (the outcome variable).

In addition to controlling for standard socio-economic characteristics and migration, we are also able to control for negative life events in childhood. TILDA respondents were asked to report whether, before turning 18 , they were physically or sexually abused by either their parents or someone else and whether their parents drank or used drugs so often that it caused problems in the family. Unsurprisingly, the number of missing observations for the negative early-life events is significantly higher than for the other controls. To avoid losing important information, we include two dummies for each event-'event occurred' and 'respondent did not provide information on the specific event' - with 'event did not occur' being the reference category.

\section{Descriptive Statistics}

Men

In Table 2 we report the mean values (and standard deviations) of all the variables used in our analysis for males. These are presented separately for stayers, short-term return migrants, long-term recent returners and long-term earlier returners. Focusing first on the outcome variables, Table 2 shows that both long-term recent and longterm earlier returners are more likely to be moderately or very isolated, according to the Berkman-Syme Social Network Index. Of stayers, 31.8 per cent are moderately or very isolated according to this index, compared to 34.2 per cent of short-term migrants, 62.3 per cent of long-term recent returners $(\mathrm{p}<0.01)$ and 45 per cent of long-term earlier returners $(\mathrm{p}<0.01)$. Table 2 also shows the four components of the index separately - compared to stayers, long-term migrants are significantly less likely to be married or cohabiting $(\mathrm{p}<0.05)$, to go to church on a regular basis $(\mathrm{p}<0.01)$ or to be a member of a community organisation $(\mathrm{p}<0.01)$. Long-term recent migrants also have fewer children, other relatives or friends they feel close to (an average of 8.5 compared to 11.6 for stayers). The average score of the modified version of the UCLA Loneliness Scale (where $0=$ not lonely and $10=$ extremely lonely) is significantly higher for long-term recent and earlier returners.

Turning to the explanatory variables, Table 2 shows that short- and long-term migrants have different characteristics and, in turn, differ across a range of variables when compared to stayers. In general terms, long-term migrants are more likely to be 
Table 2. Descriptive statistics—-male stayers, short-term migrants, long-term recent and long-term earlier returners

\begin{tabular}{|c|c|c|c|c|c|c|c|c|}
\hline & \multicolumn{2}{|c|}{ Stayers } & \multicolumn{2}{|c|}{ Short-term return migrants } & \multicolumn{2}{|c|}{ Long-term recent returners } & \multicolumn{2}{|c|}{ Long-term earlier returners } \\
\hline & Mean & SD & Mean & SD & Mean & SD & Mean & SD \\
\hline \multicolumn{9}{|l|}{ Outcome variable(s): } \\
\hline Moderately/very isolated & 0.318 & 0.466 & 0.342 & 0.475 & $0.623^{\star * *}$ & 0.489 & $0.450^{\star \star *}$ & 0.499 \\
\hline Number of close ties & 11.58 & 7.399 & 11.862 & 7.254 & $8.554^{* \star *}$ & 5.990 & 11.040 & 7.640 \\
\hline \multicolumn{9}{|c|}{ Berkman-Syme Social Network Index Components: } \\
\hline Married or cohabiting & 0.738 & 0.440 & 0.782 & 0.413 & $0.556^{\star *}$ & 0.502 & $0.660^{\star *}$ & 0.475 \\
\hline Church & 0.670 & 0.470 & $0.571^{\star \star \star}$ & 0.496 & $0.469^{* * *}$ & 0.504 & $0.539^{* * *}$ & 0.499 \\
\hline Community organisations & 0.506 & 0.500 & 0.507 & 0.501 & $0.270^{\star * *}$ & 0.448 & $0.389^{* * *}$ & 0.489 \\
\hline At least 2 close ties & 0.980 & 0.139 & 0.990 & 0.100 & 0.956 & 0.207 & 0.969 & 0.174 \\
\hline Mean UCLA Loneliness Score & 1.907 & 2.194 & 2.019 & 2.231 & $2.526^{* *}$ & 2.386 & $2.139^{*}$ & 2.252 \\
\hline \multicolumn{9}{|l|}{ Explanatory variables: } \\
\hline Age & 63.20 & 9.939 & 62.641 & 8.219 & 62.907 & 8.047 & $65.426^{* * *}$ & 8.630 \\
\hline \multicolumn{9}{|l|}{ Education dummies: } \\
\hline None/primary & 0.403 & 0.491 & $0.302^{\star * *}$ & 0.460 & 0.477 & 0.504 & $0.510^{\star * \star}$ & 0.501 \\
\hline Secondary & 0.441 & 0.497 & $0.390^{\star}$ & 0.488 & 0.371 & 0.488 & $0.354^{\star \star}$ & 0.479 \\
\hline Third/higher & 0.157 & 0.364 & $0.309^{* * *}$ & 0.463 & 0.152 & 0.363 & 0.136 & 0.344 \\
\hline \multicolumn{9}{|l|}{ Current place of residence: } \\
\hline Dublin & 0.229 & 0.420 & 0.261 & 0.441 & $0.073^{\star \star}$ & 0.262 & $0.121^{\star \star \star}$ & 0.325 \\
\hline Town or city other than Dublin & 0.271 & 0.444 & $0.332^{\star *}$ & 0.471 & $0.410^{* *}$ & 0.497 & 0.283 & 0.451 \\
\hline Rural area & 0.500 & 0.500 & $0.406^{\star * \star}$ & 0.492 & 0.517 & 0.505 & $0.596^{\star *}$ & 0.492 \\
\hline \multicolumn{9}{|l|}{ Labour market status: } \\
\hline Retired & 0.405 & 0.491 & 0.412 & 0.493 & 0.479 & 0.504 & $0.477^{* *}$ & 0.500 \\
\hline Employed & 0.458 & 0.498 & 0.454 & 0.499 & $0.209^{\star * *}$ & 0.410 & $0.337^{\star * *}$ & 0.474 \\
\hline Unemployed & 0.072 & 0.259 & 0.051 & 0.219 & $0.147^{\star}$ & 0.357 & 0.090 & 0.286 \\
\hline Permanently sick/disabled & 0.051 & 0.220 & 0.053 & 0.225 & $0.166^{\star * *}$ & 0.376 & 0.066 & 0.248 \\
\hline Other labour market status & 0.014 & 0.118 & $0.030^{\star \star}$ & 0.172 & - & - & $0.031^{*}$ & 0.173 \\
\hline Current poor self-rated health & 0.234 & 0.424 & 0.236 & 0.425 & $0.386^{\star *}$ & 0.492 & 0.279 & 0.449 \\
\hline Father is alive & 0.055 & 0.227 & 0.073 & 0.261 & 0.078 & 0.270 & 0.052 & 0.223 \\
\hline
\end{tabular}




\begin{tabular}{|c|c|c|c|c|c|c|c|c|}
\hline & \multicolumn{2}{|c|}{ Stayers } & \multicolumn{2}{|c|}{ Short-term return migrants } & \multicolumn{2}{|c|}{ Long-term recent returners } & \multicolumn{2}{|c|}{ Long-term earlier returners } \\
\hline & Mean & SD & Mean & SD & Mean & SD & Mean & SD \\
\hline Mother is alive & 0.170 & 0.376 & 0.161 & 0.368 & 0.237 & 0.429 & 0.175 & 0.381 \\
\hline Number of living children & 2.757 & 2.090 & $3.025^{\star *}$ & 1.977 & $1.824^{* * *}$ & 1.644 & $2.283^{* * *}$ & 1.912 \\
\hline Number of living siblings & 1.231 & 2.562 & 1.050 & 2.275 & 1.425 & 2.731 & 1.321 & 2.703 \\
\hline \multicolumn{9}{|l|}{ Socio-economic status in childhood: } \\
\hline Grew up in rural area & 0.621 & 0.485 & 0.597 & 0.491 & 0.735 & 0.446 & $0.701^{\star *}$ & 0.459 \\
\hline Grew up in poor family & 0.240 & 0.427 & 0.262 & 0.440 & $0.360^{*}$ & 0.485 & $0.388^{\star \star *}$ & 0.488 \\
\hline Poor health in childhood & 0.053 & 0.224 & 0.067 & 0.249 & 0.059 & 0.238 & 0.066 & 0.249 \\
\hline \multicolumn{9}{|l|}{ Negative early-life events in childhood: } \\
\hline Parents had alcohol/drug problem & 0.075 & 0.263 & $0.135^{\star * *}$ & 0.343 & 0.067 & 0.252 & 0.073 & 0.261 \\
\hline Parents had no alc./drug problem & 0.903 & 0.296 & $0.852^{\star * *}$ & 0.355 & 0.893 & 0.312 & 0.892 & 0.312 \\
\hline Missing information & 0.022 & 0.148 & 0.012 & 0.111 & 0.040 & 0.198 & 0.035 & 0.185 \\
\hline Physically or sexually abused & 0.093 & 0.291 & $0.157^{* * *}$ & 0.364 & 0.146 & 0.357 & 0.094 & 0.019 \\
\hline Not physically or sexually abused & 0.879 & 0.326 & $0.824^{* * *}$ & 0.382 & 0.828 & 0.381 & 0.882 & 0.323 \\
\hline Missing information on abuse & 0.027 & 0.164 & 0.019 & 0.138 & 0.026 & 0.159 & 0.024 & 0.152 \\
\hline $\mathrm{N}$ & \multicolumn{2}{|c|}{2,032} & \multicolumn{2}{|c|}{94} & \multicolumn{2}{|c|}{52} & \multicolumn{2}{|c|}{245} \\
\hline
\end{tabular}

Notes: ${ }^{* *} \mathrm{p}<0.01^{* *} \mathrm{p}<0.05{ }^{*} \mathrm{p}<0.10$. Data are weighted. Statistically significant differences between short-term migrants and stayers, long-term recent returners and stayers, an long-term earlier returners and stayers, are reported. 
Table 3. Descriptive statistics—-female stayers, short-term migrants, long-term recent and long-term earlier returners

\begin{tabular}{|c|c|c|c|c|c|c|c|c|}
\hline & \multicolumn{2}{|c|}{ Stayers } & \multicolumn{2}{|c|}{ Short-term return migrants } & \multicolumn{2}{|c|}{ Long-term recent returners } & \multicolumn{2}{|c|}{ Long-term earlier returners } \\
\hline & Mean & SD & Mean & SD & Mean & SD & Mean & SD \\
\hline \multicolumn{9}{|l|}{ Outcome variable(s): } \\
\hline Moderately/very isolated & 0.334 & 0.472 & $0.389^{*}$ & 0.488 & $0.463^{\star}$ & 0.503 & $0.430^{* * *}$ & 0.496 \\
\hline Number of close ties & 10.47 & 5.876 & 10.701 & 5.731 & 11.070 & 7.520 & 10.042 & 6.428 \\
\hline \multicolumn{9}{|c|}{ Berkman-Syme Social Network Index Components: } \\
\hline Married or cohabiting & 0.649 & 0.477 & $0.579^{* *}$ & 0.494 & 0.541 & 0.502 & $0.548^{\star * *}$ & 0.499 \\
\hline Church & 0.744 & 0.437 & $0.657^{* * *}$ & 0.475 & 0.696 & 0.464 & 0.720 & 0.450 \\
\hline Community organisations & 0.441 & 0.497 & $0.508^{\star *}$ & 0.501 & 0.368 & 0.486 & $0.374^{*}$ & 0.485 \\
\hline At least 2 close ties & 0.989 & 0.102 & 0.995 & 0.070 & 0.972 & 0.168 & 0.990 & 0.098 \\
\hline Mean UCLA Loneliness Score & 2.029 & 2.195 & 2.110 & 2.299 & 1.803 & 0.316 & 2.208 & 2.125 \\
\hline \multicolumn{9}{|l|}{ Explanatory variables: } \\
\hline Age & 64.31 & 10.59 & 64.900 & 9.866 & 64.235 & 9.503 & $68.304^{* * *}$ & 9.320 \\
\hline \multicolumn{9}{|l|}{ Education dummies: } \\
\hline None/primary & 0.391 & 0.488 & $0.289^{\star \star *}$ & 0.454 & 0.393 & 0.492 & $0.459^{\star}$ & 0.499 \\
\hline Secondary & 0.456 & 0.498 & $0.395^{\star *}$ & 0.489 & $0.311^{\star}$ & 0.467 & $0.361^{\star *}$ & 0.481 \\
\hline Third/higher & 0.153 & 0.361 & $0.317^{* * *}$ & 0.466 & $0.297^{* * *}$ & 0.461 & 0.180 & 0.385 \\
\hline \multicolumn{9}{|l|}{ Current place of residence: } \\
\hline Dublin & 0.245 & 0.430 & 0.270 & 0.445 & $0.055^{\star * *}$ & 0.231 & $0.135^{\star * *}$ & 0.342 \\
\hline Town or city other than Dublin & 0.271 & 0.444 & 0.295 & 0.457 & 0.263 & 0.444 & 0.287 & 0.453 \\
\hline Rural area & 0.485 & 0.500 & 0.434 & 0.496 & $0.682^{\star * *}$ & 0.470 & $0.578^{\star \star}$ & 0.495 \\
\hline \multicolumn{9}{|l|}{ Labour market status: } \\
\hline Retired & 0.264 & 0.441 & $0.330^{\star \star *}$ & 0.471 & $0.573^{\star * *}$ & 0.499 & $0.482^{\star * *}$ & 0.501 \\
\hline Employed & 0.295 & 0.456 & 0.312 & 0.464 & $0.178^{\star}$ & 0.386 & $0.222^{\star *}$ & 0.417 \\
\hline Unemployed & 0.028 & 0.165 & 0.034 & 0.181 & 0.021 & 0.146 & 0.018 & 0.133 \\
\hline Permanently sick/disabled & 0.051 & 0.220 & 0.072 & 0.260 & 0.042 & 0.202 & 0.060 & 0.238 \\
\hline Other labour market status & 0.362 & 0.481 & $0.251^{\star \star *}$ & 0.434 & $0.185^{* *}$ & 0.392 & $0.218^{* * *}$ & 0.414 \\
\hline Current poor self-rated health & 0.242 & 0.428 & 0.227 & 0.420 & 0.239 & 0.430 & $0.332^{* * *}$ & 0.472 \\
\hline Father is alive & 0.044 & 0.204 & 0.043 & 0.202 & 0.044 & 0.208 & 0.032 & 0.177 \\
\hline
\end{tabular}




\begin{tabular}{|c|c|c|c|c|c|c|c|c|}
\hline & \multicolumn{2}{|c|}{ Stayers } & \multicolumn{2}{|c|}{ Short-term return migrants } & \multicolumn{2}{|c|}{ Long-term recent returners } & \multicolumn{2}{|c|}{ Long-term earlier returners } \\
\hline & Mean & SD & Mean & SD & Mean & SD & Mean & SD \\
\hline Mother is alive & 0.157 & 0.363 & 0.148 & 0.355 & 0.206 & 0.408 & 0.125 & 0.331 \\
\hline Number of living children & 3.349 & 2.173 & 3.162 & 2.130 & $2.003^{* * *}$ & 1.491 & $2.470^{* * *}$ & 1.812 \\
\hline Number of living siblings & 1.185 & 2.572 & 1.019 & 2.253 & 1.433 & 3.015 & $0.842^{\star}$ & 2.390 \\
\hline \multicolumn{9}{|l|}{ Socio-economic status in childhood: } \\
\hline Grew up in rural area & 0.639 & 0.480 & 0.640 & 0.481 & 0.616 & 0.490 & $0.771^{* * *}$ & 0.421 \\
\hline Grew up in poor family & 0.193 & 0.395 & 0.162 & 0.369 & 0.266 & 0.445 & 0.204 & 0.404 \\
\hline Poor health in childhood & 0.071 & 0.256 & 0.070 & 0.256 & 0.096 & 0.296 & 0.088 & 0.284 \\
\hline \multicolumn{9}{|l|}{ Negative early-life events in childhood: } \\
\hline Parents had alcohol/drug problem & 0.076 & 0.265 & 0.090 & 0.286 & 0.069 & 0.255 & 0.068 & 0.252 \\
\hline Parents had no alc./drug problem & 0.901 & 0.298 & 0.879 & 0.327 & 0.920 & 0.273 & 0.915 & 0.279 \\
\hline Missing information & 0.023 & 0.149 & 0.031 & 0.174 & 0.011 & 0.104 & 0.017 & 0.129 \\
\hline Physically or sexually abused & 0.084 & 0.277 & $0.124^{* * *}$ & 0.330 & 0.096 & 0.297 & 0.071 & 0.257 \\
\hline Not physically or sexually abused & 0.885 & 0.319 & $0.828^{* * *}$ & 0.378 & 0.876 & 0.333 & $0.835^{\star}$ & 0.372 \\
\hline Missing information on abuse & 0.031 & 0.174 & 0.048 & 0.214 & 0.028 & 0.168 & $0.094^{* * *}$ & 0.293 \\
\hline $\mathrm{N}$ & \multicolumn{2}{|c|}{2,467} & \multicolumn{2}{|c|}{445} & \multicolumn{2}{|c|}{60} & \multicolumn{2}{|c|}{235} \\
\hline
\end{tabular}

Notes: ${ }^{* *} \mathrm{p}<0.01^{* *} \mathrm{p}<0.05{ }^{*} \mathrm{p}<0.10$. Data are weighted. Statistically significant differences between short-term migrants and stayers, long-term recent returners and stayers, an long-term earlier returners and stayers, are reported. 
older and poorly educated, to have grown up in a poor family or in a rural area, to be retired and to have fewer living children. On the other hand, short-term migrants are more likely to be highly educated and have more living children. Interestingly, longterm recent returners are the least likely to be in employment and the most likely to be permanently sick or disabled and to report their current health as poor.

Turning finally to negative early-life events, Table 2 shows that 9.3 per cent of stayers report having been sexually or physically abused before turning 18 , compared to 15.7 per cent of short-term return migrants $(\mathrm{p}<0.01), 14.6$ per cent of long-term recent returners and 9.4 per cent of long-term earlier returners. Also, 7.5 per cent of stayers report that their parents were drinking/taking drugs so often that it caused problems in the family, compared to 13.5 per cent of short-term migrants $(p<0.01)$. This supports the view that, although economic reasons were a key determinant of emigration from Ireland in the second half of the twentieth century, a desire to escape from situations might also have played an important role for some.

\section{Women}

Table 3 shows that a different picture emerges for women-both short- and longterm female migrants are more likely to be moderately or very isolated, according to the Berkman-Syme Social Network Index. Among stayers, 33.4 per cent are moderately or very isolated according to this index, compared to 38.9 per cent of short-term migrants $(\mathrm{p}<0.10), 46.3$ per cent of long-term recent returners $(\mathrm{p}<0.06)$ and 43 per cent of long-term earlier returners $(\mathrm{p}<0.01)$. However, there are no statistically significant differences in the number of close ties between stayers and return migrants. Also, short-term return migrants are the most likely to participate in a community organisation but the least likely to go to church on a regular basis. Finally, there are no statistically significant differences in the mean loneliness scores of female stayers and migrants.

Table 3 also shows that short- and long-term female migrants have different characteristics, although these seem to be less clear-cut than for men. Compared to stayers, long-term migrants are more likely to be older, to have grown up or live in a rural area and to have fewer living children. Table 3 furthermore shows that 36.2 per cent of stayers fall into the labour market category 'other', which mostly includes women who are looking after home or family. This compares to 25.1 per cent for short-term migrants, 18.5 per cent for long-term recent returners and 21.8 per cent for long-term earlier returners. Similarly, 26.4 per cent of stayers, 33 per cent of short-term migrants, 57.3 per cent of long-term recent returners and 48.2 per cent of long-term earlier returners are retired. This supports the view that the majority of women who left Ireland in their youth were 'economic agents' and spent time in employment as opposed to inactivity when living abroad. This seems to be particularly the case for long-term migrants. As for men, short-term female migrants are also more likely to report having been sexually or physically abused before turning 18. 


\section{Results}

\section{Men}

Table 4 shows the results of Models 1, 2 and 3 for men. Marginal effects and standard errors are presented for Models 1 and 3 (probit and tobit models), and coefficients and standard errors for Model 2 (OLS model). ${ }^{3}$

Table 4. Results of social isolation and loneliness models-men

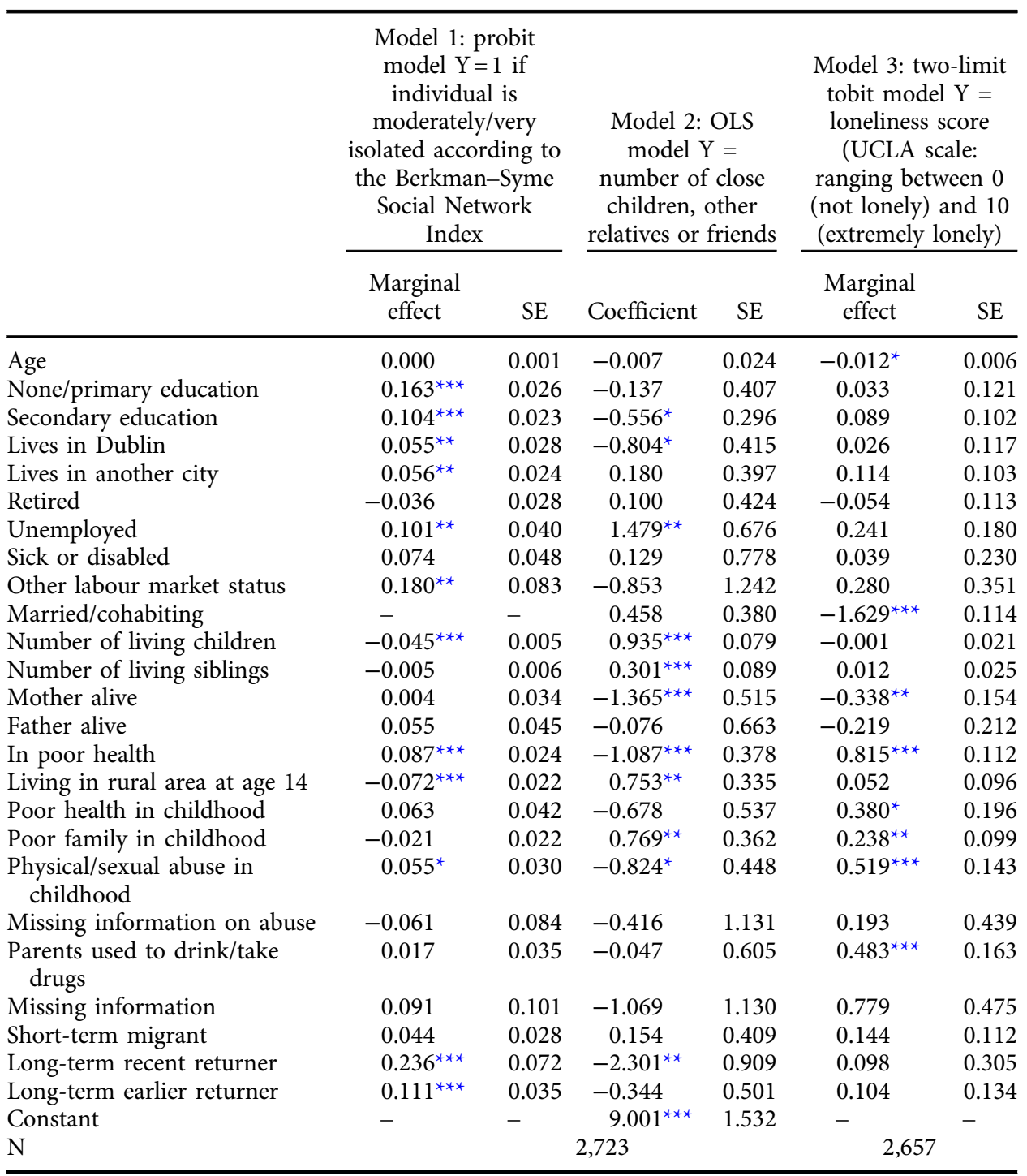

Notes: ${ }^{* *} \mathrm{p}<0.01{ }^{* *} \mathrm{p}<0.05{ }^{*} \mathrm{p}<0.10$. Data are weighted. Reference categories are: third/higher level of education; lives in a rural area; in employment; physically or sexually abused; parents did not have an alcohol problem or use drugs; and stayer. In Model 3, marginal effects describe how the observed dependent variable changes with respect to the regressors. 
Focusing first on the migration variables in Model 1, Table 4 shows that both long-term recent and long-term earlier returners are more likely to be moderately or very isolated when isolation is defined using (the adapted version of) the BerkmanSyme Social Network Index. The probability of being moderately or very isolated is 23.6 per cent points higher for long-term recent returners $(\mathrm{p}<0.01)$ and 11.1 per cent points higher for long-term earlier returners $(p<0.01)$ than for stayers. The results of Model 2 also show that long-term recent returners have-on average- 2.3 fewer close ties than stayers $(\mathrm{p}<0.05)$. Our results seem to suggest that there are no statistically significant differences in the social participation/presence of close ties between shortterm migrants and stayers. However, long-term migrants-and especially long-term recent returners - are at higher risk of social isolation. Turning to loneliness, we do not find evidence that return migrants are more likely to be more lonely than stayers.

\section{Women}

Table 5 shows the results of Model 1 and 2 for women. Focusing first on the migration variables in Model 1, Table 5 shows that female return migrants generally are more likely to be moderately or very isolated. There also seems to be an 'isolation gradient', with short-term migrants being the least likely to be at risk of isolation, followed by long-term earlier and then long-term recent returners. Compared to stayers, the probability of being moderately or very isolated is 5.4 per cent points higher for short-term migrants $(\mathrm{p}<0.06), 8.9$ per cent points higher for long-term earlier returners $(\mathrm{p}<0.05)$ and 15.4 per cent points higher for long-term recent returners $(\mathrm{p}<0.05)$.

However, the results of Models 2 and 3 show that there are no statistically significant differences in the number of close ties and the loneliness score between female stayers, short-term migrants and long-term migrants.

As a final robustness check, we investigate whether 'unobserved heterogeneity' biases our results. By 'unobserved heterogeneity', we mean that it is possible that returned migrants and stayers differ in ways which are not observed in the data but which impact upon the results. For example, if some people form fewer social ties and this leads them to be more mobile, then we might observe higher degrees of social isolation among migrants without there being a causal relationship running from migration to social isolation. In order to investigate this, we use the instrumental variable (IV) approach. ${ }^{4}$ A discussion of the technicalities of this model is beyond the scope of this paper but the details are available in a companion working paper (Barrett and Mosca 2012). The results of the IV models are in line with those of the standard models investigated above. We therefore conclude that that the results of the standard models of Tables 4 and 5 are not biased.

\section{Conclusions}

We began the paper by raising the possibility that migrants may face re-adjustment difficulties when they return to live in their countries of origin. Our results suggest 
Table 5. Results of social isolation and loneliness models-women

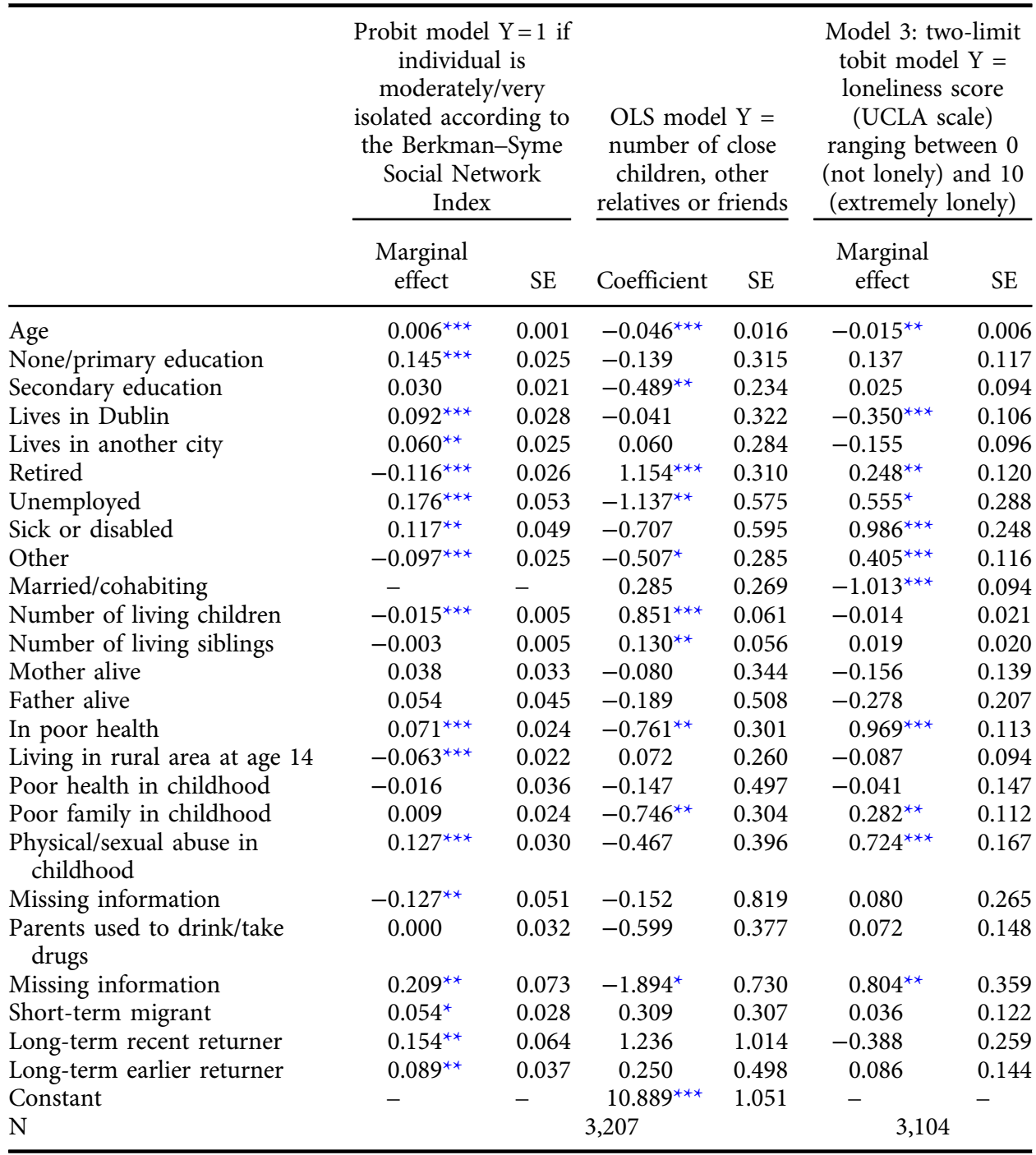

Notes: ${ }^{* * *} \mathrm{p}<0.01{ }^{* *} \mathrm{p}<0.05{ }^{*} \mathrm{p}<0.10$. Data are weighted. Reference categories are: third/higher level of education; lives in a rural area; in employment; physically or sexually abused; parents did not have an alcohol problem or use drugs; and stayer. In Model 3, marginal effects describe how the observed dependent variable changes with respect to the regressors.

that social isolation is a significant feature of the lives of both male and female return migrants and that the degree of social isolation is typically stronger for people who spent longer away or who have returned more recently.

Our results are based on the quantitative analysis of a large dataset but the results are consistent with those from qualitative research on the experiences of returning migrants, some of which we discussed above. For example, Ryan (2008) described the 
re-adjustment challenges faced by Irish nurses as they returned to Ireland after spending their careers in England. Their sense of disconnection has echoes in our findings of social isolation. While the study by Skrbis was concerned with visits home by migrants as opposed to return migration, a number of the themes are very relevant. Skrbis described a process through which migrants 'construct their image of home in a distinctly nostalgic and romantic fashion' (2007: 315). To the extent that such images are not realised upon returning to the home country, return migration presents a range of challenges which could exceed some of those presented by an initial migratory move. Ní Laoire made similar points when she wrote about the experiences of people moving to rural settings after lives lived in urban areas. While all movers are at risk of disappointment if their notion of some rural idyll is unfulfilled, 'the disappointment may be particularly acute among return migrants whose expectations may be partly based on memories from childhood and on return visits' (2007: 342). This disappointment is evident in many of the interviews reported upon by Ní Laoire.

While we did find clear evidence of greater degrees of social isolation among returned migrants, we did not find evidence of higher degrees of loneliness. Although both recent and earlier long-term male return migrants are more likely to feel lonely when one controls only for migration, the effect disappears when a wide range of controls_-including self-reported health and marital status - are added to the model. This leads to the question of why Irish older return migrants are more likely to be socially isolated but not more likely to feel lonely.

One possible explanation is that the return migrants in our sample have gone through a process of adaptation over the years so, although they are less likely to participate in clubs, go to church, be married or cohabiting or to have fewer close ties, they do not feel that they are missing intimate relationships or a wider network. In other words, return migrants might have learnt to be 'self-sufficient' individuals and/ or to have developed a coping mechanism. An alternative explanation is that the modified version of the UCLA Loneliness Scale is not a good measure with which to capture loneliness among TILDA respondents. The average loneliness score in the TILDA sample is relatively low: around 2, on a scale from 0 (not lonely) to 10 (lonely). As argued by Timonen et al. (2011: 61), 60 per cent of respondents in TILDA who are 'objectively' socially isolated report that they never feel isolated from others.

Previous research has also shown that there are profound cultural differences in the perception of loneliness. More than two decades of research on loneliness have shown that -in contrast to what one might intuitively think-loneliness amongst older people is higher in Southern than in Northern Europe. Sundström et al. (2009) used data from the first wave of the Survey of Health, Ageing and Retirement in Europe (SHARE) to compare loneliness across countries. They focused their analysis on the question 'How often have you experienced the feeling of loneliness over the last week?' and dichotomised loneliness into 'substantial loneliness' (almost all or most of the time) versus 'less frequent feelings of loneliness' (some or almost none of the 
time). They found that around 12 per cent of respondents aged 65+ felt 'substantially lonely' in the week prior to the interview. However, substantial loneliness ranged from 4 per cent in Switzerland, 5 per cent in Denmark and 7 per cent in Sweden to 18 per cent in Italy and 20 per cent in Greece. The loneliness question is slightly different in TILDA, but 'only' 8 per cent of respondents aged $65+$ say that they often feel lonely. Hence, Ireland seems to be a country with low levels of reported loneliness amongst older people.

While the findings on loneliness are open to different interpretations, we do seem to have uncovered clear evidence that return migrants experience higher degrees of social isolation. From the perspective of the individual, such isolation is clearly a cost of migration although it may not be fully appreciated when initial migration decisions are made. To the extent that this later-life social isolation resulting from migration and return is anticipated, it may help to explain patterns of migration and return. From a broader social perspective, the presence of large numbers of return migrants in countries such as Ireland leads to concerns of social isolation among these people with the potential consequences for health—both physical and mental—and care needs.

\section{Acknowledgements}

We thank two anonymous JEMS referees and the JEMS Managing Editor, Jenny Money, for their insightful comments and suggestions. We also thank Peter Muhlau and seminar participants at the University of Oxford and TILDA. All errors are our own.

\section{Notes}

[1] This is an approximation because we assume that migrants spent a single period of time abroad. In reality, this might not be the case-migrants can have alternated periods of time spent in Ireland with periods of time spent abroad. However, our data do not allow us to distinguish between single and multiple migration experiences.

[2] Only three people in our sample can be classified as short-term recent returners. Hence, we do not distinguish for time since return for short-term migrants.

[3] Different marginal effects can be computed in tobit models. In Model 3, marginal effects describe how the observed dependent variable (which is bounded between 0 and 10) changes with respect to the regressors.

[4] As instrument, we use the unemployment rates for the years in which the individuals in our sample would have been deciding whether or not to migrate.

\section{References}

Barrett, A. (2005) 'Irish migration: characteristics, causes and consequences', in Zimmermann, K.F. (ed.) European Migration: What Do We Know? Oxford: Oxford University Press, 89-112.

Barrett, A. and Mosca, I. (2012) Social Isolation and Return Migration: Evidence from Older Irish Adults. Bonn: IZA Discussion Paper No. 6331.

Berkman L.F. and Syme, S.L. (1979) 'Social networks, host resistance, and mortality: a nine-year follow-up study of Alameda County residents', American Journal of Epidemiology, 109(2): 186-204.

Böhning, W. (1987) Studies in International Migration. New York: St Martin's Press. 
Cerase, F.P. (1967) 'A study of Italian migrants returning from the USA', International Migration Review, 1(3): 67-74.

Cerase, F.P. (1970) 'Nostalgia or disenchantment: considerations on return migration', in Tomasi, S.M. and Engel, M.H. (eds) The Italian Experience in the US. New York: Center for Migration Studies, 217-39.

Cerase, F.P. (1974) 'Expectations and reality: a case study of return migration from the United States to Southern Italy', International Migration Review, 8(2): 245-62.

Christou, A. (2006) 'American dreams and European nightmares: experiences and polemics of second-generation Greek-American returning migrants', Journal of Ethnic and Migration Studies, 32(5): 831-45.

Conroy, R.M., Golden, J., Jeffares, I., O'Neill, D. and McGee, H. (2010) 'Boredom-proneness, loneliness, social engagement and depression and their association with cognitive function in older people: a population study', Psychology, Health and Medicine, 15(4): 463-73.

Constable, N. (1999) 'At home but not at home: Filipina narratives of ambivalent returns', Cultural Anthropology, 14(2): 203-28.

Glass, T.A., De Leon, D.F., Bassuk, S.S. and Berkman, L.F. (2006) 'Social engagement and depressive symptoms in late life: longitudinal findings', Journal of Aging and Health, 18(4): 604-28.

Glytsos, N.P. (1988) 'Remittances and temporary migration: a theoretical model and its testing with the Greek-German experience', Weltwirtschaftliches Archiv, 124(3): 524-49.

Gmelch, G. (1986) 'The readjustment of return migrants in Western Ireland', in King, R. (ed.) Return Migration and Regional Economic Problems. London: Croom Helm, 152-70.

Gmelch, G. (1987) 'Return migration to rural Ireland', in Buechler, H. (ed.) Migrants in Europe: The Role of Family, Labor and Politics. Westport: Greenwood Press, 265-82.

Grenade, L. and Boldy, D. (2008) 'Social isolation and loneliness among older people: issues and future challenges in community and residential settings', Australian Health Review, 32(3): 468-78.

Hawkley, L.C., Thisted, R.A., Masi, C.M. and Cacioppo, J.T. (2010) 'Loneliness predicts increased blood pressure: 5-year cross-lagged analyses in middle-aged and older adults', Psychology and Aging, 25(1): 132-41.

Kenny, R.A., Whelan, B.J., Cronin, H., Kamiya, Y., Kearney, P., O’Regan, C. and Ziegel, M. (2010) The Design of the Irish Longitudinal Study on Ageing. http://www.tcd.ie/tilda/assets/pdf/ DesignReport2010.pdf.

Leavey, G., Sembhi, S. and Livingston, G. (2004) 'Older Irish migrants living in London: identity, loss and return', Journal of Ethnic and Migration Studies, 30(4): 763-79.

Long, L. and Oxfeld, E. (2004) Coming Home: Refugees, Migrants and Those Who Stayed Behind. Philadelphia: University of Pennsylvania Press.

McGrath, F. (1991) 'The economic, social and cultural impacts of return migration to Achill Island', in King, R. (ed.) Contemporary Irish Migration. Dublin: Geographical Society of Ireland, 55-69.

NESC (1991) The Economic and Social Implications of Emigration. Dublin: National Economic and Research Council.

Ní Laoire, C. (2007) 'The "green, green grass of home"? Return migration to rural Ireland', Journal of Rural Studies, 23(3): 332-44.

Ní Laoire, C. (2008) 'Complicating host-newcomer dualisms: Irish return migrants as homecomers or newcomers?', Translocations: Migration and Social Change, 4(1): 35-50.

O'Luanaigh, C. and Lawlor, B.A. (2008) 'Loneliness and the health of older people', International Journal of Geriatric Psychiatry, 23(12): 1213-21.

Rodriguez, C.J., Elkind, M.S., Clemow, L., Jin, Z., Di Tullio, M., Sacco, R.L., Homma, S. and BodenAlbala, B. (2011) 'Association between social isolation and left ventricular mass', American Journal of Medicine, 124(2): 164-70. 
Russell, D. (1996) 'The UCLA loneliness scale (version 3): reliability, validity, and factor structure', Journal of Personality Assessment, 66(1): 20-40.

Ryan, L. (2008) 'Becoming nurses: Irish women, migration and identity through the life course', in Ryan, L. and Webster, W. (eds) Gendering Migration: Masculinity, Femininity and Ethnicity in Post-War Britain. Aldershot: Ashgate, 121-35.

Savva, G. (2011) 'Methodology', in Barrett, A., Savva, G., Timonen, V. and Kenny, R.A. (eds) Fifty Plus in Ireland 2011: First Results from The Irish Longitudinal Study on Ageing (TILDA), 293303. http://www.tcd.ie/tilda/publications/reports/.

Seeman, T., Miller-Martinez, D., Stein-Merkin, S., Lachman, M.E., Tun, P.A. and Karlamangla, A.S. (2010) 'Histories of social engagement and adult cognition in middle and late life: the Midlife in the US study', Journal of Gerontology, 66B(1): i141-52.

Sexton, J. (1996) Report to OECD Continuous Reporting System on Migration (SOPEMI). Dublin: Economic and Social Research Institute.

Sinclair, I., Parker, R., Leat, D. and Williams, J. (1990) The Kaleidoscope of Care: A Review of Research on Welfare Provision for Elderly People. London: HMSO.

Sirven, N. and Debrand, T. (2008) 'Social participation and healthy ageing: an international comparison using SHARE data', Social Science and Medicine, 67(12): 2017-26.

Skrbis, Z. (2007) 'From migrants to pilgrim tourists: diasporic imagining and visits to Medjugorje', Journal of Ethnic and Migration Studies, 33(2): 313-29.

Sundström, G., Fransson, E., Malmberg, B. and Davey, A. (2009) 'Loneliness among older Europeans', European Journal of Ageing, 6(4): 267-75.

Timonen, V., Kamiya, Y. and Maty, S. (2011) 'Social engagement of older people', in Barrett, A., Savva, G., Timonen, V. and Kenny, R.A. (eds) Fifty Plus in Ireland 2011: First Results from The Irish Longitudinal Study on Ageing (TILDA), 51-72. http://www.tcd.ie/tilda/publications/ reports/.

Wenger, C., Davies, R., Shahtahmasebi, S. and Scott, A. (1996) 'Social isolation and loneliness in old age: review and model refinement', Ageing and Society, 16(3): 333-58. 